\title{
Eksplorasi Keterampilan Penalaran Ilmiah Berdasarkan Jenis Kelamin Siswa SMA
}

\author{
Sahal Fawaiz ${ }^{1}$, Supriyono Koes Handayanto ${ }^{1}$, Herwin Syaiful Wahyudi ${ }^{2}$ \\ ${ }^{1}$ Pendidikan Fisika, Universitas Negeri Malang \\ ${ }^{2}$ SMAN 1 Asembagus
}

\section{INFO ARTIKEL}

\section{Riwayat Artikel:}

Diterima: 12-06-2020

Disetujui: 16-07-2020

\section{Kata kunci:}

scientific reasoning skills; gender;

high school student;

keterampilan penalaran ilmiah; jenis kelamin;

siswa SMA

\section{Alamat Korespondensi:}

\section{ABSTRAK}

Abstract: Scientific reasoning skills are very important for students to be obtained as their future provisions considering they are firmly related to problem solving and critical thinking skills. The purpose of this study was to identify high school students' SRA based on gender in Situbondo Regency. This research method is quantitative descriptive utilizing a sample of 195 high school students selected utilizing purposive sampling. The instrument consisted of 26 open-ended multiple-choice questions with a reliability coefficient $\alpha=0.797$. The results of this research indicate that the distinctions in SRA between male and female students are inexistent. However, female students have a slightly higher average SRS value and outperform the SRS level achievement of male students, spesifically on correlational reasoning, probabilistic reasoning, and hyphotetico-deductive reasoning. In addition, most of students $(84,10 \%)$ remain on the concrete operational level and this indicates that the students' SRSs is still low. Combinatorial reasoning considered as the lowest achievement indicators whilst correlation reasoning indicators quite the opposite. Based on the findings, the implication based on theory and practices have been discussed.

Supriyono Koes Handayanto

Pendidikan Fisika

Universitas Negeri Malang

Jalan Semarag 5 Kota Malang

E-mail: supriyono.koeshandayanto.fmipa@um.ac.id

Salah satu keterampilan yang erat kaitannya dengan prestasi belajar (Tajudin \& Chinnappan, 2016; Thuneberg et al., 2015) dan ikut andil dalam kesuksesan siswa (Thompson et al., 2018) adalah Keterampilan Penalaran Ilmiah. Keterampilan Penalaran Ilmiah merupakan kemampuan siswa dalam mengolah informasi berdasarkan observasi langsung dan mengambil kesimpulan yang lebih kompleks dari objek yang diamati (Lawson, 2004). Keterampilan Penalaran Ilmiah menerapkan prinsip penyelidikan ilmiah, mulai dari mengajukan hipotesis, merencanakan, mendesain, melakukan percobaan hingga menarik kesimpulan (Zimmerman \& Klahr, 2018) sehingga keterampilan ini berpengaruh dalam proses pembelajaran. Siswa dapat dengan mudah menyelesaikan suatu permasalahan jika memiliki Keterampilan Penalaran Ilmiah yang tinggi (Hejnová et al., 2018; Hong et al., 2014), juga kritis dalam memilah informasi (Develaki, 2017).

Jenis kelamin merupakan salah satu faktor separasi dari sebagian besar penelitian perkembangan keterampilan anak dan proses pembelajaran di bidang pendidikan. Perbedaan jenis kelamin telah diselidiki pada berbagai macam keterampilan, seperti keterampilan metakognitif (Ciascai \& Lavinia, 2011), keterampilan dasar numerik (Hutchison et al., 2019), keterampilan spasial (Maeda \& Yoon, 2013; Mäntylä, 2013; Reilly \& Neumann, 2013), cara belajar (Bonomo, 2010), memandang sains (Ong 
\& Lai, 2006), melakukan regulasi diri (Baer \& Kaufman, 2008), keterampilan penalaran (Aartsen et al., 2004; Flores-Mendoza et al., 2013; Lakin, 2013; Lynn \& Irwing, 2002). Keterampilan-keterampilan ini memiliki korelasi yang positif sehingga dapat menjadi prediktor kesuksesan siswa dalam proses belajar. Pada penelitian sebelumnya, sebuah reanalisis terhadap dua metaanalisis oleh Becker, (1989) menjelaskan bahwa laki-laki lebih unggul dalam bidang biologi, IPA, dan fisika, namun tidak ditemukan perbedaan pada bidang geologi, kimia, dan ilmu campuran. Scheiber et al., (2015) juga melakukan penelitian skala besar tentang prestasi belajar berdasarkan jenis kelamin, dimana hasilnya perempuan lebih dominan dalam hal membaca dan menulis, tetapi kedua jenis kelamin tidak berbeda dalam bidang matematika. Tambahan juga di dunia olimpiade matematika dan sains, prestasi laki-laki lebih menonjol ketimbang perempuan dengan perbedaan terkecil ditemukan pada bidang olimpiade biologi (Steegh et al., 2019).

Selain mempertimbangkan kemungkinan variasi Keterampilan Penalaran Ilmiah siswa laki-laki dan perempuan, masih banyak ditemukan ketidaksesuaian usia terhadap level perkembangan kognitif siswa ditinjau berdasarkan KPI masih banyak ditemukan. Pada tingkat sekolah menengah atas ditemukan sebagian besar siswa masih berada pada tingkat operasional konkret (Effendy et al., 2018; Khoirina et al., 2018; Puspita, 2016), hal serupa juga pada tingkat sekolah menengah pertama (Novianawati \& Nahadi, 2019; Rosdiana et al., 2019). Eksplorasi KPI terhadap calon guru fisika juga dilakukan oleh Sriyansyah \& Saepuzaman, (2016) dan mahasiswa fisika oleh Handayanto et al., (2019), keduanya memperoleh hasil yang sama dimana sebagian besar berada pada tahap transisi. Hasil yang berbeda diperoleh pada guru biologi yang sebagian besar masih berada pada tahap operasional konkret (Ermayanti et al., 2019; Nurdiani et al., 2019).

Beberapa penelitian eksplorasi KPI sebelumnya telah dilakukan berdasarkan jenis kelamin siswa menggunakan instrumen Lawson, (1978, 2000). Pada siswa kelas VIII (Acar, Büber, et al., 2015; Acar, Türkmen, et al., 2015), siswa kelas XI (Tajudin \& Chinnappan, 2016), dan remaja berumur sebelas hingga tujuh belas tahun (Talib et al., 2018) telah dievaluasi KPI mereka dan ditemukan tidak ada perbedaan yang signifikan di antara siswa laki-laki dan perempuan. Lebih spesifik lagi, c menyelidiki perbedaan KPI beserta masing-masing keenam indikator, dan hasil yang sama yaitu tidak ditemukan perbedaan yang signifikan berdasarkan kedua jenis kelamin. Bahkan, hasil penelitian Thuneberg et al., (2015) yang menyelidiki perbedaan salah satu indikator KPI yaitu control of variable berdasarkan jenis kelamin masih saja memperoleh hasil yang serupa. Sebaliknya, ditemukan hasil yang berbeda oleh Nieminen et al., (2013) pada siswa di sekolah menengah atas, dimana KPI lakilaki lebih unggul daripada perempuan.

Namun demikian, masih jarang ditemukan penelitian eksplorasi untuk menyelidiki perbedaan Keterampilan Penalaran Ilmiah yang juga meninjau pada tujuh indikator Keterampilan Penalaran Ilmiah sesuai dengan penelitian Lawson, (1978, 2000) pada domain fisika berdasarkan perbedaaan jenis kelamin. Berdasarkan uraian tersebut, penelitian ini bertujuan untuk mengidentifikasi perbedaan KPI siswa SMA berdasarkan jenis kelamin pada materi fluida di Kabupaten Situbondo pada tahun pelajaran 2019/2020. Level KPI siswa juga mendapat perhatian khusus dalam penelitian ini dan diharapkan hasilnya dapat menjadi bahan evaluasi oleh para guru dalam merancang pembelajaran di kelas.

\section{METODE \\ Partisipan}

Sampel pada penelitian ini sebanyak 195 siswa (144 = siswa perempuan) sekolah menengah atas di Kabupaten Situbondo Tahun Pelajaran 2019/2020. Siswa berumur rata-rata (M=17,0667 tahun; SD=0,32215 tahun). Berdasarkan hasil wawancara, siswa belum pernah mengikuti tes KPI sebelumnya, dan kemampuan Bahasa Indonesia yang mereka miliki berada pada kriteria "baik" dan "sangat baik" berdasarkan data dari guru Bahasa Indonesia di sekolah masing-masing.

\section{Prosedur}

Data yang terkumpul pada penelitian ini diperoleh melalui satu sesi tes tulis selama 90 menit. Kemudian beberapa peserta dipilih menggunakan teknik random sampling untuk sesi wawancara, yang mana jumlah siswa yang diwawancara pada masing-masing kelas $(n=2)$, dengan jumlah seluruh kelas $(\mathrm{N}=6)$. Pada sesi wawancara, siswa diberi 7 butir soal yang bertujuan untuk memverifikasi jawaban siswa pada tes tulis.

\section{Instrumen Tes Keterampilan Penalaran Ilmiah}

Penelitian ini menggunakan modifikasi instrumen soal tes pilihan ganda beralasan terbuka berdasarkan Lawson, (1978, 2000) dengan jumlah 26 butir soal meliputi tujuh indikator KPI pada materi fluida (Cronbach alpha $=0,797$ ). Soal berupa polytomous telah dianalisis menggunakan teori respon butir dengan metode Rasch Partial Credit Model (InMSQ (0,869$1,204), \mathrm{p}=0,742$ ) menggunakan aplikasi Xcalibre 4.2. 


\section{Tabel 1. Indikator Keterampilan Penalaran Ilmiah}

\begin{tabular}{llc}
\hline \multicolumn{1}{c}{ Indikator } & Nomor Soal & Skor Maksimal \\
\hline Penalaran Konservasi & $5,7,9,10,23$ & 4 \\
Penalaran Proporsional & $3,11,12,22$ & 4 \\
Control of Variable & $17,18,19,20,21$ & 5 \\
Penalaran Kombinatorial & 25,26 & 4 \\
Penalaran Probabilistik & $14,16,24$ & 3 \\
Penalaran Korelasi & $2,4,8,15$ & 4 \\
Hypothetical-Deductive Reasoning & $1,6,13$ & 5
\end{tabular}

Instrumen soal KPI telah dikembangkan mengacu pada materi fluida, baik fluida statis dan fluida dinamis. Contoh soal disajikan pada gambar 1 .

Gambar di bawah menunjukkan 4 cairan pada wadah yang berbeda bentuk. Wadah 1 dan 3 berisi air, sedangkan pada wadah 2 dan 4 berisi minyak kelapa.

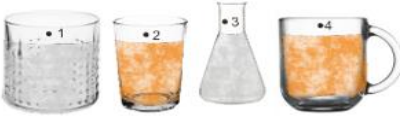

Pada keempat wadah dicelupkan corong pesawat hartl untuk membandingkan besar tekanan hidrostatis pada masing-masing wadah yang ditunjukkan oleh beda ketinggian pada pipa U.

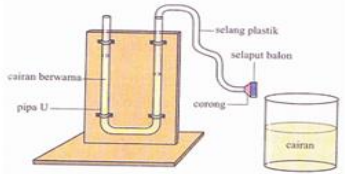

Jika kamu ingin menentukan apakah massa jenis cairan memiliki efek terhadap tekanan hidrostatis. Manakah wadah yang akan kamu gunakan?
a. 1 dan 3
b. 2 dan 3
c. 2 dan 4
d. Semua cairan
e. Hanya cairan 3

Alasan:

Penggunaan deterjen setiap kali Rozikin mencuci memudahkan hilangnya noda pada pakaian, mengapa demikian?

Berikut penjelasannya

Surfaktan/deterjen merupakan bahan aktif permukaan. Surfaktan menurunkan tegangan permukaan air dengan mematahkan ikatan-ikatan hidrogen pada permukaan. Hal ini dilakukan dengan menaruh kepala-kepala hidrofiliknya pada permukaan air dengan ekor-ekor hidrofobiknya terentang menjauhi permukaan air.

Hal yang serupa akan terjadi jika temperatur air dinaikkan. Dengan menggunakan air panas dan semua bahan tersebut, bagaimana Rozikin menguji kemungkinan tersebut?

a. Dilakukan dengan memvariasi volume air panas untuk melihat adanya perbedaan

b. Mencuci kembali, tetapi pastikan bahwa semua variabel bebasnya tetap, lalu hitung jumlah kucekan sampai noda hilang

c. Ulangi mencuci dengan deterien, dan variasi suhu air panas dengan mencatat jumlah kucekan sampai noda hilang

d. Jenis kain mempengaruhi jumlah kucekan, jadi gunakan kain jenis katun dan mencuci ulang

e. Noda bersih bergantung jumlah deterien, gunakan air panas dengan variasi takaran banyak deterien

Alasan :

Gambar 1. Contoh Soal (a) Control of Variables, (b) Hyphotetical-Deductive Reasoning 
Berdasarkan skor yang diperoleh siswa dilakukan transformasi skala untuk menentukan level keterampilan penalaran ilmiah masing-masing siswa. Kemudian siswa dikelompokkan berdasarkan jenis kelamin dan level keterampilan penalaran ilmiah mereka seperti ditunjukkan pada tabel 2.

Tabel 2. Level Keterampilan Penalaran Ilmiah

\begin{tabular}{lcc}
\hline \multicolumn{1}{c}{ Level } & Skala & Transformasi Skala \\
\hline Operasional Konkret (OK) & $5 \geq \mathrm{x}$ & $33,3 \geq \mathrm{x}$ \\
Transisis Awal (TAw) & $5<\mathrm{x} \geq 8$ & $33,3<\mathrm{x} \geq 53,3$ \\
Transisi Akhir (TAk) & $8<\mathrm{x} \geq 11$ & $53,3<\mathrm{x} \geq 73,3$ \\
Oerasional Formal (OF) & $11<\mathrm{x} \geq 15$ & $73,3<\mathrm{x} \geq 100$ \\
\hline
\end{tabular}

(Anton E. Lawson, 1978; Moore \& Slisko, 2016)

\section{Analisis Data}

Setelah tes dilaksanakan, analisis data dilakukan menggunakan SPSS v.25 untuk menghitung rata-rata, standar deviasi, uji-t, dan uji ANOVA untuk membandingkan nilai KPI berdasarkan jenis kelamin siswa.

\section{HASIL}

Berdasarkan penelitian yang telah dilakukan menggunakan instrumen tes KPI pada materi fluida, hasil penelitian menunjukkan distribusi skor KPI siswa. Sistem penskoran tes berdasarkan E. F. Karplus \& Karplus, (1970; R. Karplus, (1977, 1980); R. Karplus et al., (1980); Anton E. Lawson, (1976); White, (1984). Distribusi skor keterampilan penalaran ilmiah ditunjukkan pada tabel 3. Distribusi siswa berdasarkan level KPI ditunjukkan pada tabel 4. Distribusi keterampilan penalaran ilmiah siswa pada masing-masing jenis kelamin ditunjukkan pada gambar 2. Dimana kedua jenis kelamin didominasi oleh siswa yang berada pada level operasional konkret

Tabel 3. Distribusi Skor Rata-Rata Keterampilan Penalaran Ilmiah Siswa

\begin{tabular}{llllll}
\hline Jenis Kelamin & N & Mean & Min & Max & Std. Dev \\
\hline Laki-laki & 51 & 20,3814 & 2,75 & 53,21 & 12,2432 \\
Perempuan & 144 & 20,9289 & 0 & 55,96 & 11,8630 \\
Total & 195 & 20,7857 & 0 & 55,96 & 11,9342 \\
\hline
\end{tabular}

Tabel 4. Distribusi Siswa berdasarkan Level Keterampilan Penalaran Ilmiah

\begin{tabular}{|c|c|c|c|c|}
\hline Level & Jenis Kelamin & Jumlah Siswa & Persentase & Total Persentase \\
\hline \multirow[t]{2}{*}{ OK } & Laki-laki & 45 & $27,44 \%$ & \multirow[b]{2}{*}{$84,10 \%$} \\
\hline & Perempuan & 119 & $72,56 \%$ & \\
\hline \multirow[t]{2}{*}{ TAw } & Laki-laki & 6 & $20 \%$ & \multirow[b]{2}{*}{$15,38 \%$} \\
\hline & Perempuan & 24 & $80 \%$ & \\
\hline \multirow[t]{2}{*}{ TAk } & Laki-laki & 0 & $0 \%$ & \multirow[b]{2}{*}{$0,51 \%$} \\
\hline & Perempuan & 1 & $100 \%$ & \\
\hline \multirow[t]{2}{*}{$\mathrm{OF}$} & Laki-laki & 0 & $0 \%$ & \multirow[b]{2}{*}{$0 \%$} \\
\hline & Perempuan & 0 & $0 \%$ & \\
\hline
\end{tabular}




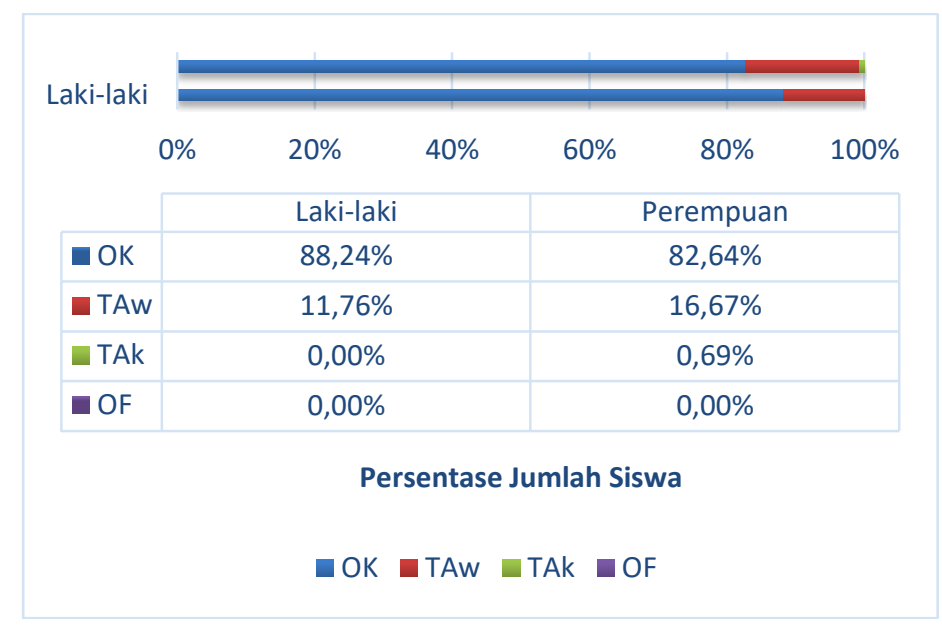

\section{Gambar 2. Grafik Level Keterampilan Penalaran Ilmiah berdasarkan Jenis Kelamin}

Hasil uji-t secara keseluruhan dan dan uji ANOVA pada masing-masing indikator menunjukkkan nilai signifikansi di atas 0,05 sehingga tidak ada perbedaan yang signifikan di antara kedua jenis kelamin seperti ditunjukkan pada tabel 5 dan 6 .

Tabel 5. Hasil Uji-t untuk Keterampilan Penalaran Ilmiah Siswa berdasarkan Jenis Kelamin

\begin{tabular}{lllc}
\hline & t & df & Sig (2-tailed) \\
\hline Equal variances assumed & $-0,375$ & 193 & 0,708 \\
Equal variances not assumed & -0.363 & 82,864 & 0,718 \\
\hline
\end{tabular}

Tabel 6. Hasil Tes ANOVA pada Setiap Indikator Keterampilan Penalaran Ilmiah Siswa

\begin{tabular}{|c|c|c|c|c|c|c|}
\hline Indikator & & Sum of Squares & df & Mean Square & $\mathbf{F}$ & Sig. \\
\hline \multirow[t]{3}{*}{ PKons } & Between Groups & 130 & 1 & 0,130 & 0,07 & 0,934 \\
\hline & Within Groups & 3646,824 & 193 & 18,895 & & \\
\hline & Total & 3646,954 & 194 & & & \\
\hline \multirow[t]{3}{*}{ PProp } & Between Groups & 116 & 1 & 0,116 & 0,015 & 0,903 \\
\hline & Within Groups & 1502,222 & 193 & 7,784 & & \\
\hline & Total & 1502,338 & 194 & & & \\
\hline \multirow[t]{3}{*}{$\mathrm{COV}$} & Between Groups & 109,934 & 1 & 10,934 & 0,737 & 0,392 \\
\hline & Within Groups & 2864,738 & 193 & 14,843 & & \\
\hline & Total & 2875,672 & 194 & & & \\
\hline \multirow[t]{3}{*}{ PKom } & Between Groups & 1,779 & 1 & 1,779 & 3,272 & 0,072 \\
\hline & Within Groups & 104,908 & 193 & 0,544 & & \\
\hline & Total & 106,687 & 194 & & & \\
\hline \multirow[t]{3}{*}{ PProb } & Between Groups & 1,036 & 1 & 1,036 & 0,264 & 0,608 \\
\hline & Within Groups & 757,149 & 193 & 3,923 & & \\
\hline & Total & 758,185 & 194 & & & \\
\hline \multirow[t]{3}{*}{ PKor } & Between Groups & 24,266 & 1 & 24,266 & 2,096 & 0,149 \\
\hline & Within Groups & 2234,349 & 193 & 11,577 & & \\
\hline & Total & 2258,615 & 194 & & & \\
\hline \multirow[t]{3}{*}{ HDR } & Between Groups & 17,653 & 1 & 17,653 & 1,852 & 0,175 \\
\hline & Within Groups & 1839,301 & 193 & 9,530 & & \\
\hline & Total & 1856,954 & 194 & & & \\
\hline
\end{tabular}




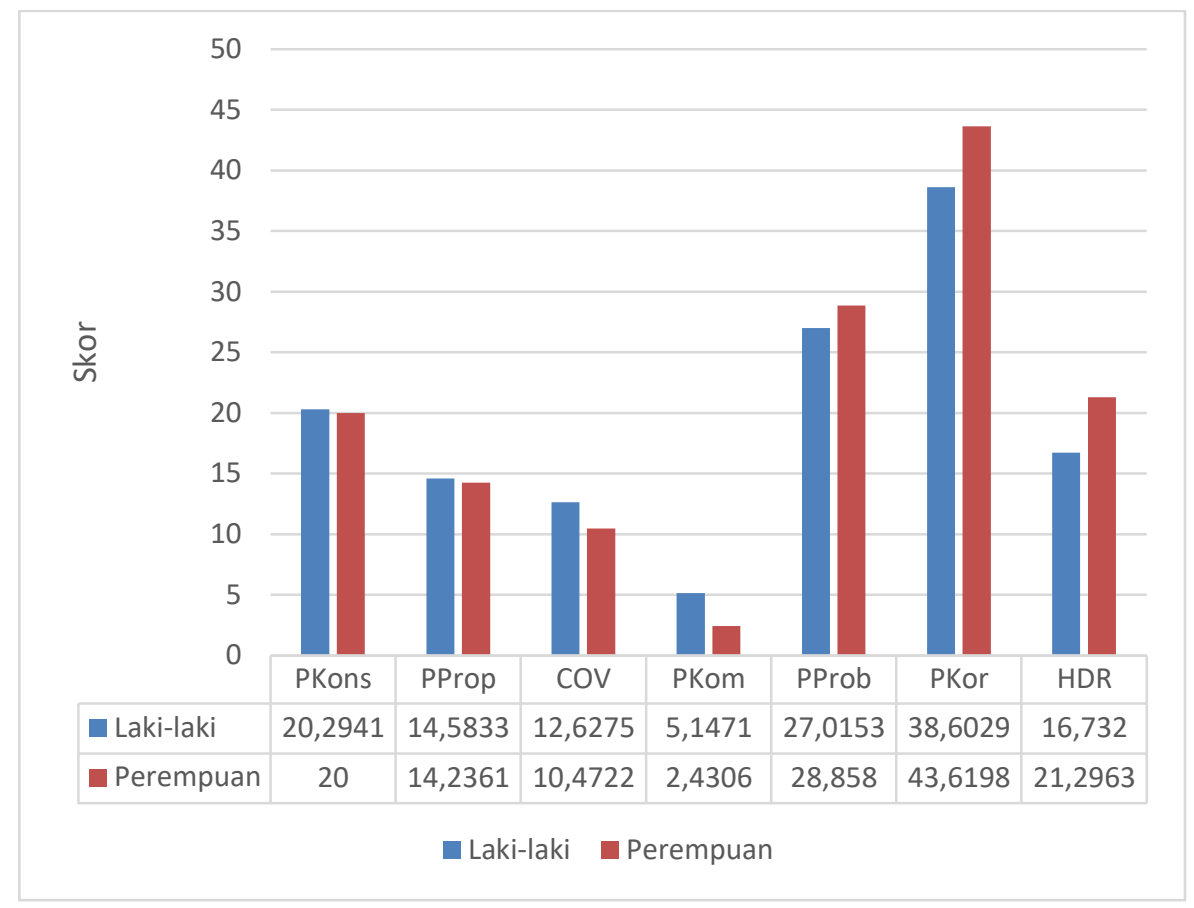

Gambar 3. Grafik Keterampilan Penalaran Ilmiah pada Masing-masing Sub Indikator berdasarkan Jenis Kelamin

\section{PEMBAHASAN}

\section{Level Keterampilan Penalaran Ilmiah Siswa}

Berdasarkan pada tabel 4 sebagian besar siswa berada pada tahap OK sebanyak 84,10\%, kemudian sebanyak $15,38 \%$ pada tingkat TAw, 0,51\% pada tingkat TAk, dan tidak ditemukan siswa pada rentang tingkat operasional formal. Penelitian ini selaras dengan penelitian Jufri et al., (2016); Khoirina et al., (2018); Rimadani, Parno, \& Diantoro, (2017); Yediarani et al., (2019), dimana sebagian besar siswa masih berada pada tahap operasional konkret. Hal ini mengindikasikan keterampilan penalaran ilmiah siswa masih rendah. Hasil ini bertentangan dengan teori perkembangan kognitif oleh Piaget (1964) karena terjadi keterlambatan perkembangan kognitif anak, dimana seharusnya anak berada pada tahap ini saat berusia 6-12 tahun. Tahap operasional konkret merupakan tingkat ketiga dalam perkembangan kognitif, pada tahap ini anak dapat menghubungkan kategori dengan operasi dan kebalikannya (Byrnes, 2019) serta mampu mempertimbangkan asosisasi dan melakukan klasifikasi objek (Babakr, et al., 2019). Keterlambatan perkembangan Keterampilan Penalaran Ilmiah siswa dimungkinkan oleh beberapa sebab, seperti masih belum dilatihnya KPI secara tepat pada proses pembelajaran.

Pada setiap level KPI, siswa perempuan mendominasi pada level transisi, baik TAw maupun Tak, sedangkan Level OK berisi mayoritas siswa laki-laki. Hasil ini tertera pada gambar 2. Bagaimanapun, siswa perempuan mengungguli siswa lakilaki berdasarkan pencapaian level Keterampilan Penalaran Ilmiah.

\section{Perbedaan Keterampilan Penalaran Ilmiah}

Hasil yang diperoleh tidak lagi mengejutkan, dimana tidak ada perbedaan signifikan Keterampilan Penalaran Ilmiah siswa laki-laki dibandingkan siswa perempuan yang ditunjukkan pada tabel 5. Begitupula pada tabel 6 menunjukkan bahwa pada ketujuh indikator KPI, tidak ditemukan perbedaan yang signifikan di antara kedua jenis kelamin. Temuan ini konsisten dengan penelitian sebelumnya (Aartsen et al., 2004; Acar, Büber, et al., 2015; Acar, Türkmen, et al., 2015; Piraksa et al., 2014; Tajudin \& Chinnappan, 2016; Talib et al., 2018; Thuneberg et al., 2015). Hasil ini juga didukung berkenaan dengan volume otak manusia yang memengaruhi kecerdasan individu. Meskipun secara umum otak laki-laki lebih besar daripada perempuan, namun secara luas volume otak relatif dan jika diverifikasi kembali berdasarkan ukuran tubuh, volume otak di antara kedua jenis kelamin sama (Ankney, 1992). Meskipun demikian, siswa perempuan memilki nilai mean yang sedikit lebih tinggi daripada laki-laki dalam KPI. Hasil ini mengonfirmasi penelitian Alshamali \& Daher, (2016); Talib et al., (2018). 


\section{Capaian Indikator Keterampilan Penalaran Penalaran Ilmiah}

Capaian indikator terendah KPI pada penelitian ini adalah penalaran kombinatorial dan capaian indikator tertinggi ialah penalaran korelasi. Kedua indikator yaitu PKor dan PProb dicapai oleh siswa di atas rata-rata. Hasil tersebut bertentangan dengan Novianawati \& Nahadi, (2019), hasil ini dimungkinkan karena perbedaan instrumen yang digunakan yaitu TOLT oleh (Tobin \& Capie, 1981) dan atau pengetahuan awal siswa (Croker \& Buchanan, 2011; Zeineddin \& Abd-El-Khalick, 2010). Siswa perempuan mengungguli siswa laki-laki pada indikator penalaran korelasi, penalaran probabilistik, dan hyphoteticodeductive reasoning, dimana hasil penelitian ini sangat kontras dengan penelitian Piraksa et al., (2014).

Siswa perempuan sedikit lebih rendah daripada siswa laki-laki pada indikator penalaran proporsional. Rasio antara dua variabel atau lebih untuk mengetahui ketergantungan antar variabel cenderung menggunakan matematika untuk operasinya. Hasil ini didukung oleh (Mackenzie, 1988), bahwasanya sejak kelas VII perempuan menganggap matematika tidak penting untuk karir masa depan mereka sehingga mereka memiliki minat dan kepercayaan diri yang rendah ketika berhubungan dengan matematika. Hal ini yang menyebabkan siswa perempuan tidak mengungguli laki-laki pada indikator penalaran proporsi.

Rendahnya tingkat Keterampilan Penalaran Ilmiah siswa dapat dijadikan acuan guru untuk merancang proses pembelajaran. Guru dapat fokus untuk mendesain model dan metode pembelajaran yang cocok untuk melatih Keterampilan Penalaran Ilmiah siswa, tanpa memperhatikan perbedaan identitas masing-masing siswa, seperti jenis kelamin. Guru dapat menerapkan pembelajaran inkuiri (Andersen \& Garcia-Mila, 2017; Chen \& She, 2014), pembelajaran berbasis masalah (Misnasanti et al., 2017), dan pembelajaran berbasis komputer (Al-Balushi et al., 2016; Bork, 1993; She \& Liao, 2010) juga dengan scaffolding (Rashid et al., 2017).

\section{SIMPULAN}

Berdasarkan hasil penelitian, jenis kelamin tidak memiliki perbedaan yang signifikan pada KPI siswa ( $p>0,05)$, baik secara keseluruhan maupun per indikator. Sebagian besar siswa berada pada tingkat operasional konkret $(84,10 \%)$, dimana hal ini menunjukkan keterampilan penalran ilmiah siswa di Kabupaten Situbondo masih rendah. Siswa memiliki performa baik dalam penalaran probabilistik $(28,38 \%)$ dan penalaran korelasi $(42,31 \%)$, namun siswa memiliki capaian rendah pada penalaran kombinatorial $(3,14 \%)$. Diharapkan hal ini dapat menjadi acuan bagi para guru untuk memilih metode pembelajaran yang tepat untuk melatih KPI siswa.

Penelitian ini menggunakan tes pilihan ganda beralasan terbuka sehingga dimungkinkan masih adanya tebakan dari siswa. Dengan demikian, untuk penelitian selanjutnya dapat menggunakan soal berbentuk esai. Serta dapat diselidiki lebih lanjut dengan materi fisika yang berbeda, jika ditinjau berdasarkan kompleksitas materi.

\section{DAFTAR RUJUKAN}

Aartsen, M. J., Martin, M., \& Zimprich, D. (2004). Gender Differences in Level and Change in Cognitive Functioning: Results from the Longitudinal Aging Study Amsterdam. Gerontology, 50(1), 35-38. https://doi.org/10.1159/000074387

Acar, Ö., Büber, A., \& Tola, Z. (2015). The Effect of Gender and Socio-economic Status of Students on Their Physics Conceptual Knowledge, Scientific Reasoning, and Nature of Science Understanding. Procedia - Social and Behavioral Sciences, 174, 2753-2756. https://doi.org/10.1016/j.sbspro.2015.01.962

Acar, Ö., Türkmen, L., \& Bilgin, A. (2015). Examination of Gender Differences on Cognitive and Motivational Factors that Influence $8^{\text {th }}$ Ömer Acar Graders' Science Achievement in Turkey. Eurasia Journal of Mathematics, Science and Technology Education, 11(5), 1027-1040. https://doi.org/10.12973/eurasia.2015.1372a

Al-Balushi, S. M., AL-Musawi, A. S., \& Ambusaidi, A. K. (2016). The Effectiveness of Interacting with Scientific Animations in Chemistry Using Mobile Devices on Grade 12 Students' Spatial Ability, and Scientific Reasoning Skills. Journal of Science Education and Technology, 26(1), 70-81. https://doi.org/10.1007/s10956-016-9652-2 The

Alshamali, M. A., \& Daher, W. M. (2016). Scientific Reasoning and Its Relationship with Problem Solving: the Case of Upper Primary Science Teachers. International Journal of Science and Mathematics Education, 14(6), 1003-1019. https://doi.org/10.1007/s10763-015-9646-1

Andersen, C., \& Garcia-Mila, M. (2017). Scientific Reasoning During Inquiry. Science Education, 105-117. https://doi.org/10.1007/978-94-6300-749-8_8

Ankney, C. D. (1992). Sex Differences in Relative Brain Size: The Mismeasure of Woman, Too? Intelligence, 16(3-4), 329336. https://doi.org/10.1016/0160-2896(92)90013-H

Babakr, Z. H., Mohamedamin, P., \& Kakamad, K. (2019). Piaget's Cognitive Developmental Theory: Critical Review. Education Quarterly Reviews, 2(3), 517-524. https://doi.org/10.31014/aior.1993.02.03.84

Baer, J., \& Kaufman, J. C. (2008). Gender Differences in Creativity. Journal of Creative Behavior, 42(2), 75-105.

Becker, B. J. (1989). Gender and Science Achievement: A Reanalysis of Studies from Two Meta-Analyses. Journal of Research in Science Teaching, 26(2), 141-169. https://doi.org/10.1002/tea.3660260206 
Bonomo, V. (2010). Gender Matters in Elementary Education Research-based Strategies to Meet the Distinctive Learning Needs of Boys and Girls Distinctive Learning Needs of Boys and Girls in Elementary Education Those Findings Do Not Necessarily Mean that Boys Learn One. Educational Horizons, 88(4), 257-264.

Bork, A. (1993). Learning Scientific Reasoning with the Interactive Computer. Journal of Science Education and Technology, 2(1), 335-348. https://doi.org/10.1007/BF00694596

Byrnes, J. P. (2019). Piaget's Cognitive-Developmental Theory. In Encyclopedia of Infant and Early Childhood Development (Issue April, pp. 543-552). https://doi.org/10.1016/B978-0-12-809324-5.23519-0

Chen, C. T., \& She, H. C. (2014). The Effectiveness of Scientific Inquiry with/without Integration of Scientific Reasoning. International Journal of Science and Mathematics Education, 13(1), 1-20. https://doi.org/10.1007/s10763-013-9508-7

Ciascai, L., \& Lavinia, H. (2011). Gender Differences in Metacognitive Skills. A Study of the 8th Grade Pupils in Romania. Procedia - Social and Behavioral Sciences, 29, 396-401. https://doi.org/10.1016/j.sbspro.2011.11.255

Croker, S., \& Buchanan, H. (2011). Scientific Reasoning in a Real World Context: The Effect of Prior Belief and Outcome on Children's Hypothesis-Testing Strategies. British Journal of Developmental Psychology, 29(3), 409-424. https://doi.org/10.1348/026151010X496906

Develaki, M. (2017). Using Computer Simulations for Promoting Model-based Reasoning. Science \& Education, 26(7-9), 1001-1027. https://doi.org/10.1007/s11191-017-9944-9

Effendy, S., Hartono, \& Yulianti, I. (2018). The Ability of Scientific Reasoning and Mastery of Physics Concept of State Senior High School Students in Palembang City. International Conference on Science and Education and Technology 2018, 247, 504-509. https://doi.org/10.2991/iset-18.2018.102

Ermayanti, Anwar, Y., \& Zein, D. (2019). Analyzing Scientific Reasoning Skills of Biology Prospective Teachers. Journal of Physics: Conference Series, 1166(1). https://doi.org/10.1088/1742-6596/1166/1/012002

Flores-Mendoza, C., Widaman, K. F., Rindermann, H., Primi, R., Mansur-Alves, M., \& Pena, C. C. (2013). Cognitive Sex Differences in Reasoning Tasks: Evidence from Brazilian Samples of Educational Settings. Intelligence, 41(1), 70-84. https://doi.org/10.1016/j.intell.2012.11.002

Handayanto, S. K., Hidayat, A., \& Kusairi, S. (2019). The Scientific Reasoning Profile of Physics Students after Following STEM Learning. International Conference on Learning Innovation (ICLI 2018), 363-366. https://doi.org/10.5220/0008412203630366.

Hejnová, E., Eisenmann, P., Cihlář, J., \& Přribyl, J. (2018). Relations between Scientific Reasoning, Culture of Problem Solving and Pupil'S School Performance. Journal on Efficiency and Responsibility in Education and Science, 11(2), 38-44. https://doi.org/10.7160/eriesj.2018.110203

Hong, J. C., Hwang, M. Y., Liao, S., Lin, C. S., Pan, Y. C., \& Chen, Y. L. (2014). Scientific Reasoning Correlated to Altruistic Traits in an Inquiry Learning Platform: Autistic vs. Realistic Reasoning in Science Problem-Solving practice. Thinking Skills and Creativity, 12, 26-36. https://doi.org/10.1016/j.tsc.2013.12.002

Hutchison, J. E., Lyons, I. M., \& Ansari, D. (2019). More Similar Than Different: Gender Differences in Children's Basic Numerical Skills Are the Exception Not the Rule. Child Development, 90(1), e66-e79. https://doi.org/10.1111/cdev.13044

Jufri, A. W., Setiadi, D., \& Sripatmi. (2016). Scientific Reasoning Ability of Prospective Student Teacher in the Excellence Program of Mathematics and Science Teacher Education in University of Mataram. Jurnal Pendidikan IPA Indonesia, 5(1), 69-74. https://doi.org/10.15294/jpii.v5i1.5792

Karplus, E. F., \& Karplus, R. (1970). Intellectual Development Beyond Elementary School I Deductive Logic. School Science and Mathematics, 70(5), 398-406.

Karplus, R. (1977). Proportional Reasoning and Control. Journal of Research in Science Teaching, 14(5), $411-417$.

Karplus, R. (1980). Teaching for the Development of Proportional Reasoning. Research in Science Education, 10, 1-10.

Karplus, R., Adi, H., \& Lawson, A. E. (1980). Intellectual Development Beyond Elementary School VIII: Proportional, Probabilistic, and Correlational Reasoning. School Science and Mathematics, 80(8), 673-683. https://doi.org/10.1111/j.1949-8594.1980.tb09964.x

Khoirina, M., Cari, C., \& Sukarmin. (2018). Identify Students' Scientific Reasoning Ability at Senior High School. Journal of Physics: Conference Series, 1097(1). https://doi.org/10.1088/1742-6596/1097/1/012024

Lakin, J. M. (2013). Sex differences in reasoning abilities: Surprising Evidence that Male-Female Ratios in the Tails of the Quantitative Reasoning Distribution Have Increased. Intelligence, 41(4), 263-274. https://doi.org/10.1016/j.intell.2013.04.004

Lawson, Anton E. (1976). M-space: Is it a Constraint on Conservation Reasoning Ability? Journal of Experimental Child Psychology, 22(1), 40-49. https://doi.org/10.1016/0022-0965(76)90087-4

Lawson, Anton E. (1978). The Development and Validation of a Classroom Test of Formal Reasoning. Journal of Research in Science Teaching, 15(1), 11-24. https://doi.org/10.1002/tea.3660150103 
Lawson, A. E. (2004). The Nature and Development of Scientific Reasoning: A Synthetic View. International Journal of Science and Mathematics Education, 2(3), 307-338. https://doi.org/10.1007/s10763-004-3224-2

Lynn, R., \& Irwing, P. (2002). Sex Differences in General Knowledge, Semantic Memory and Reasoning Ability. British Journal of Psychology, 93(4), 545-556. https://doi.org/10.1348/000712602761381394

Mackenzie, B. (1988). Sex Differences in Mathematical Reasoning Ability: Causes, Consequences, and Variability. Behavioral and Brain Sciences, 11(2), 201-202. https://doi.org/10.1017/S0140525X00049475

Maeda, Y., \& Yoon, S. Y. (2013). A Meta-Analysis on Gender Differences in Mental Rotation Ability Measured by the Purdue Spatial Visualization Tests: Visualization of Rotations (PSVT:R). Educational Psychology Review, 25(1), 69-94. https://doi.org/10.1007/s10648-012-9215-x

Mäntylä, T. (2013). Gender Differences in Multitasking Reflect Spatial Ability. Psychological Science, 24(4), 514-520. https://doi.org/10.1177/0956797612459660

Misnasanti, Utami, R. W., \& Suwanto, F. R. (2017). Problem Based Learning to Improve Proportional Reasoning of Students in Mathematics Learning. AIP Conference Proceedings, 1868. https://doi.org/10.1063/1.4995129

Moore, J. C., \& Slisko, J. (2016). Dynamic Visualizations of Multi-body Physics Problems and Scientific Reasoning Ability: A Threshold to Understanding. In Key Competences in Physics Teaching and Learning (pp. 155-164). https://doi.org/10.1007/978-3-319-44887-9

Nieminen, P., Savinainen, A., \& Viiri, J. (2013). Gender Differences in Learning of the Concept of Force, Representational Consistency, and Scientific Reasoning. International Journal of Science and Mathematics Education, 11(5), 1137-1156. https://doi.org/10.1007/s10763-012-9363-y

Novianawati, N., \& Nahadi, N. (2019). An Investigation of Reasoning Ability at the Secondary Level Students. Journal of Physics: Conference Series, 1157(2). https://doi.org/10.1088/1742-6596/1157/2/022061

Nurdiani, N., Rustaman, N. Y., Setiawan, W., \& Priyandoko, D. (2019). Reasoning Patterns and Modes of Prospective Biology Teachers on Embryology Learning with TPACK Framework. Jurnal Pendidikan Biologi Indonesia, 5(1), 93-100. https://doi.org/10.22219/jpbi.v5i1.7375

Ong, C., \& Lai, J. (2006). Gender Differences in Perceptions and Relationships Among Dominants of E-Learning Acceptance. Computers in Human Behavior, 22, 816-829. https://doi.org/10.1016/j.chb.2004.03.006

Piaget, J. (1964). Part I: Cognitive development in children: Piaget development and learning. Journal of Research in Science Teaching, 2(3), 176-186. https://doi.org/10.1002/tea.3660020306

Piraksa, C., Srisawasdi, N., \& Koul, R. (2014). Effect of Gender on Student's Scientific Reasoning Ability: A Case Study in Thailand. Procedia - Social and Behavioral Sciences, 116, 486-491. https://doi.org/10.1016/j.sbspro.2014.01.245

Puspita, D. I. (2016). Analisis Tingkat Kemampuan Scientific Reasoning Siswa SMA Kelas X IPA se Kota Tegal. Prosiding Seminar Nasional Sains dan Entrepreneurship III Tahun 2016, 2002, 198-205.

Rashid, A. H. A., Shukor, N. A., \& Tasir, Z. (2017). Using Computer-Based Scaffolding to Improve Students' Reasoning Skills in Collaborative Learning. 2016 IEEE 8th International Conference on Engineering Education: Enhancing Engineering Education Through Academia-Industry Collaboration, ICEED 2016, 137-142. https://doi.org/10.1109/ICEED.2016.7856059

Reilly, D., \& Neumann, D. L. (2013). Gender-Role Differences in Spatial Ability: A Meta-Analytic Review. Sex Roles, 68(910), 521-535. https://doi.org/10.1007/s11199-013-0269-0

Rimadani, E., Parno., \& Diantoro, M. (2017). Identifikasi Kemampuan Penalaran Ilmiah Siswa SMA pada Materi Suhu dan Kalor. Jurnal Pendidikan: Teori, Penelitian, dan Pengembangan, 2(6), 833-839.

Rosdiana, R., Siahaan, P., \& Rahman, T. (2019). Mapping the Reasoning Skill of the Students on Pressure Concept. Journal of Physics: Conference Series, 1157(2). https://doi.org/10.1088/1742-6596/1157/2/022036

Scheiber, C., Reynolds, M. R., Hajovsky, D. B., \& Kaufman, A. S. (2015). Gender Differences in Achievement in a Large, Nationally Representative Sample of Children and Adolescents. Psychology in the Schools, 52(4), 335-348. https://doi.org/10.1002/pits

She, H. C., \& Liao, Y. W. (2010). Bridging Scientific Reasoning and Conceptual Change Through Adaptive Web-Based Learning. Journal of Research in Science Teaching, 47(1), 91-119. https://doi.org/10.1002/tea.20309

Sriyansyah, S. P., \& Saepuzaman, D. (2016). Prospective Physics Teachers' Consistency and Scientific Reasoning in the Learning of Force Concept. International Conference of Mathematics and Science Education (ICMSEd 2016), 57, $21-24$. https://doi.org/10.2991/icmsed-16.2017.5

Steegh, A. M., Höffler, T. N., Keller, M. M., \& Parchmann, I. (2019). Gender Differences in Mathematics and Science Competitions: A Systematic Review. Journal of Research in Science Teaching, 56(10), 1431-1460. https://doi.org/10.1002/tea.21580

Tajudin, M., \& Chinnappan, M. (2016). Relationship Between Scientific Reasoning Skills and Mathematics Achievement among Malaysian Students. Geografia - Malaysian Journal of Society and Space, 12(1), 96-107. 
Talib, C. A., Rajan, S. T., Hakim, N. W. A., Malik, A. M. A., Siang, K. H., \& Ali, M. (2018). Gender Difference as a Factor in Fostering Scientific Reasoning Skill among Students. 2018 IEEE 10th International Conference on Engineering Education, ICEED 2018, 54-58. https://doi.org/10.1109/ICEED.2018.8626888

Thompson, E. D., Bowling, B. V., \& Markle, R. E. (2018). Predicting Student Success in a Major's Introductory Biology Course via Logistic Regression Analysis of Scientific Reasoning Ability and Mathematics Scores. Research in Science Education, 48(1), 151-163. https://doi.org/10.1007/s11165-016-9563-5

Thuneberg, H., Hautamäki, J., \& Hotulainen, R. (2015). Scientific Reasoning, School Achievement and Gender: a Multilevel Study of between and within School Effects in Finland. Scandinavian Journal of Educational Research, 59(3), 337-356. https://doi.org/10.1080/00313831.2014.904426

Tobin, K. G., \& Capie, W. (1981). The Development and Validation of a Group Test of Logical Thinking. Educational and Psychological Measurement, 1, 413-423.

White, H. (1984). The Development of Combinatorial Reasoning: The Role of Cognitive Capacity. Journal of Genetic Psychology, 145(2), 185-193. https://doi.org/10.1080/00221325.1984.10532266

Yediarani, R. D., Maison, M., \& Syarkowi, A. (2019). Scientific Reasoning Abilities Profil of Junior High School Students in Jambi. Indonesian Journal of Science and Education, 3(1), 21. https://doi.org/10.31002/ijose.v3i1.627

Zeineddin, A., \& Abd-El-Khalick, F. (2010). Scientific Reasoning and Epistemological Commitments: Coordination of Theory and Evidence Among College Science Students. Journal of Research in Science Teaching, 47(9), 1064-1093. https://doi.org/10.1002/tea.20368

Zimmerman, C., \& Klahr, D. (2018). Development of Scientific Thinking. In Stevens' Handbook of Experimental Psychology and Cognitive Neuroscience. https://doi.org/10.1002/9781119170174.epcn407 